\title{
Home treatment for chronic respiratory insufficiency: the situation in Europe in 1992
}

\author{
B. Fauroux, P. Howard, J.F. Muir \\ For The European Working Group on Home Treatment for Chronic Respiratory Insufficiency supported \\ by the Rehabilitation and Chronic Care group of The European Respiratory Society \\ and The International Union Against Tuberculosis and Lung Disease
}

Home treatment for chronic respiratory insufficiency: the situation in Europe in 1992. B. Fauroux, P. Howard, J.F. Muir, for The European Working Group on Home Treatment for Chronic Respiratory Insufficiency supported by the Rehabilitation and Chronic Care group of The European Respiratory Society and The International Union Against Tuberculosis and Lung Disease. CERS Journals Ltd 1994.

ABSTRACT: The search for improved quality of life and a reduction in health care costs is leading to the development of home treatment. The organization of home treatment for chronic respiratory patients in 13 European countries was evaluated at the end of 1992 by means of a questionnaire.

Switzerland and the Association Nationale pour le Traitement A Domicile de I'Insuffisance Respiratoire Chronique (ANTADIR) in France maintain registers for patients on oxygen therapy, mechanical ventilation and sleep disorders. Sweden and Poland have a national register for patients receiving oxygen. In other countries, some information can be obtained from the National Health Service or the commercial provider. Oxygen concentrators are used preferentially in all countries except Italy, Denmark, Spain and The Netherlands. Home ventilator treatment is generally performed by volume-cycled ventilators. National prescription rules exist in some parts of Spain, Switzerland and Belgium. In other countries, such as Germany, prescriptions rely on recommendations elaborated by specialists or international guidelines. Service and equipment are provided by national organizations, health services, commercial companies or hospitals. Home supervision of the patient is performed by a nurse and/or a doctor and equipment maintenance by a technician.

Important differences exist between countries in Europe in home treatment of chronic respiratory disease. Comparative analysis should help achieve uniform standards and provide a basis for future research.

Eur Respir J., 1994, 7, 1721-1726.
Members of the European Working Group on Home Treatment for Chronic Respiratory Insufficiency: P. Dubois, F. Smeets (Belgium); D. Viskum (Denmark); B. Fauroux, J.F. Muir, D. Robert, E. Chailleux, ANTADIR (France); A. Wilke, G. Laier-Groenveld (Germany); P. Howard, J. Shneerson, J. Waterhouse (England); L. Clancy, P. Kelly (Ireland); C. Donner (Italy); M. Kampelmacher (The Netherlands); U. Aasebo (Norway); J. Zielinski, M. Tobiasz (Poland); J. Escarrabill (Spain); K. Ström (Sweden); M. Pfister, R. de Haller (Switzerland).

Correspondence: B. Fauroux

ANTADIR

66 Bd St Michel

75006 Paris

France

Keywords: Chronic respiratory insufficiency home treatment

mechanical ventilation

oxygen therapy

Received: January 121994

Accepted after revision June 121994
Chronic respiratory disease continues to increase in industrialized countries. The use of tobacco products and improved survival principally account for the increase in numbers of patients with chronic respiratory insufficiency (CRI).

The search for improvements in quality of life and a reduction in health care costs is leading to the development of home treatment [1]. Long-term oxygen therapy (LTOT) and mechanical ventilation (MV) are two major treatments for CRI from either pulmonary, skeletal or neuromuscular origin $[2,3]$. With recent developments in sleep-related disorders, continuous positive airway pressure (CPAP) ventilation is increasing. Important differences exist between countries in medical home care of CRI patients. Comparison of estimated numbers of patients and their treatment, the organization of home care, the supply of material and the financial organization is of interest. The two major aims of this analysis are to establish an outline of the situation in Europe and allow countries to benefit from the experience of others.

\section{Methods}

An informal group from within the European Respiratory Society (ERS: Rehabilitation and Chronic Care) and the International Union Against Tuberculosis and Lung Disease met in 1992. Specialists in chronic respiratory care from 13 countries compared notes.

The general organization for home care of CRI was evaluated by means of a questionnaire at the end of 1992 . Information on home treatments (LTOT, MV and CPAP), prescribers of such treatments, prescription trends and practical organization of home care (supply of material, supervision of patients and equipment) were sought. Data were collected by the Association Nationale pour le 
Traitement A Domicile de l'Insuffisance Respiratoire Chronique (ANTADIR) (France). For information on therapy, some countries were able to provide complete information (for example, through a national register). Others could only offer partial information, estimated from samples obtained from the health service or a commercial company. In a few countries, even this partial information was difficult to obtain.

\section{Results}

\section{General information}

Complete information on patients treated included diagnostic information (either obstructive, restrictive or mixed pulmonary disease), age and sex, equipment supplied, (table 1), service provided and therapeutic schedules.

The level of information available differed according to the type of therapy (table 2). Information was easier to obtain for LTOT than for MV. The current status in Sweden clearly illustrates this situation. A national register of patients receiving LTOT for chronic hypoxaemia due to respiratory failure of varying origin was started by the Swedish Society of Chest Medicine in 1987 [4]. Patients under LTOT at home are also registered in Poland, where LTOT was introduced in 1986 [5]. These national registers gave interesting analyses on survival [6-13]. Switzerland has also had a national register for both LTOT and MV since 1990 through its specialized Association for Tuberculosis and Lung Disease. The country is divided into 26 cantons, and for each canton precise numbers of ventilators, oxygen concentrators, CPAP units, inhalers, aspirators and oxygensparing devices are indexed. In Norway and Denmark, a national register for LTOT has recently been started and hopes to provide similar information.

From 1981, in France, the associative system ANTADIR has managed 32 national regions, covering approximatively $70 \%$ of patients receiving home treatment for CRI. Since 1984, a subsection of about $80 \%$ of ANTADIR's patients have been surveyed to provide a precise annual report about patient status and their equipment [10]. A major outcome has been survival analysis $[10,11]$.

Table 1. - Equipment in use in the home

Oxygen cylinders
Oxygen concentrators
Liquid oxygen
Portable oxygen
Oxygen-conserving devices
Pressure-cycled ventilators
Volume-cycled ventilators
Negative pressure ventilators
Phrenic nerve stimulators
Continuous positive airway pressure machines
Bilevel pressure machines
Aspirators
Humidifiers
Nebulizers

Partial information (usually age and sex of the recipient) and the oxygen prescription for patients receiving LTOT can be obtained from analysis of Health Service data in Belgium. The organization of the country into different districts as in Denmark, Italy or Germany, or community care areas as in Ireland, complicates the collection of national information [12].

A national register exists for liquid oxygen only in Norway. In Spain, a separate register for LTOT exists in some regions. Complete information can be obtained for home treatment via a reimbursement system in Catalonia, but there is no information for other areas of Spain [14, 15]. In Great Britain and The Netherlands, precise information about LTOT and MV is difficult to obtain [16]. In England, information about oxygen concentrators can be obtained from the commercial supply companies, but this does not include diagnostic information. The British Thoracic Society plans a national register of home mechanical ventilation.

Complete information on MV can be obtained in Denmark, Spain (Catalonia), Belgium, Switzerland and France, but only the latter two countries have a national register for home $\mathrm{MV}$.

Important differences exist in the number of patients treated with CPAP for obstructive sleep apnoea (OSA). In 1982, France had more than 5,000 patients treated for OSA and it is now thought that $0.3-5.0 \%$ of the population may have the syndrome [17]. There are fewer patients in Belgium, Denmark, Italy, Poland and Switzerland. In England, Germany and Sweden, only partial information can be obtained but the numbers, at least in England, are likely to be much less than in France. Agreed schedules of diagnostic tests should evolve in order to prevent inappropriate prescription and excessive medical costs.

\section{Equipment provided}

In all countries, both adults and children receive LTOT at home for lung disease and other less common problems, such as chest wall deformities and sequelae of tuberculosis. Poland is the only country where oxygen is prescribed only for lung diseases [5]. The oxygen source differs between countries (table 2). Cylinders are used by $80 \%$ of the patients in Denmark, Spain and The Netherlands, whereas $80 \%$ of the patients receive liquid oxygen in Italy. The other countries, such as England, have a preference for concentrators; these constitute the only oxygen source in Poland. Ireland and Germany cannot provide an estimate of proportional use because of the existence of different community care areas [12]. Liquid oxygen has recently been introduced for the mobile patient in Sweden and Belgium.

Both adults and children receive $\mathrm{MV}$ at home for chronic lung disease, neuromuscular disease, chest wall deformities and central hypoventilation in all countries, except in Denmark and Poland where this treatment is almost unknown in the home. Volume-cycled ventilators only are used in Italy and Belgium, and most other countries use them predominantly. England uses volume and pressure-cycled ventilators equally, plus a significant 
Table 2. - Level of information that can be obtained in Europe concerning home treatment for chronic respiratory care (update: December 1992)

\begin{tabular}{|c|c|c|c|c|c|c|c|c|c|c|c|c|c|}
\hline & Belgium & Denmark & England & France & Germany & Ireland & Italy & $\begin{array}{l}\text { The } \\
\text { Netherlands }\end{array}$ & Norway & Poland & $\begin{array}{c}\text { Spain } \\
\text { (Catalonia) }\end{array}$ & Sweden & Switzerland \\
\hline \multicolumn{14}{|c|}{ Level of information about number of patients on home treatment } \\
\hline LTOT & On approval & Complete & Partial & Complete* & Partial & Partial & Partial & Partial & Partial & Yes & Catalonia & Complete & Complete \\
\hline MV & via & Complete & Partial & on $70 \%$ of & Complete & Partial & Partial & Yes & Partial & Few & complete & Partial & \\
\hline CPAP & NHS & Partial & Partial & patients & Partial & Partial & Partial & No & Partial & $\begin{array}{l}\text { patients } \\
\text { Yes }\end{array}$ & & Complete & \\
\hline $\begin{array}{c}\text { Information about patients } \\
\text { disease }\end{array}$ & $\begin{array}{l}\text { On approval } \\
\text { via } \text { NHS }\end{array}$ & No & No & $70 \%$ & Partial & Partial & Yes & $\begin{array}{l}\text { Yes } \\
\text { No }\end{array}$ & $\begin{array}{l}\text { For LTOT } \\
\text { only }\end{array}$ & $\begin{array}{l}\text { Yes } \\
\text { Yes }\end{array}$ & & $\begin{array}{l}\text { For LTOT } \\
\text { only }\end{array}$ & Complete \\
\hline Source of oxygen & & & & NTADIR/private & & & & & & & & & \\
\hline Gas cylinder & - & $80 \%$ & Yes & $2 \% / 20 \%$ & Yes & No liquid & $5 \%$ & $80 \%$ & $45 \%$ & $1 \%$ & $84 \%$ & $14 \%$ & Very few \\
\hline Liquid oxygen & $33 \%$ & - & No & $13 \% / 40 \%$ & Yes & oxygen & $80 \%$ & $5 \%$ & $10 \%$ & - & $1 \%$ & $1 \%$ & - \\
\hline Concentrator & $67 \%$ & $20 \%$ & Yes & $85 \% / 40 \%$ & Yes & $\begin{array}{l}\text { concentrators } \\
\text { essentially }\end{array}$ & $15 \%$ & $15 \%$ & $45 \%$ & $99 \%$ & $15 \%$ & $85 \%$ & $100 \%$ \\
\hline \multicolumn{14}{|l|}{ Mechanical ventilation } \\
\hline Volume-cycled ventilation & Yes & Yes & Yes & Yes & Yes & Yes & Yes & Yes & Yes & - & Yes & Yes & Yes \\
\hline Pressure-cycled ventilation & No & Yes & Yes & Yes & Yes & Yes & No & Few & Yes & - & - & - & Very few \\
\hline Int neg $\mathrm{P}$ ventilation & No & - & Yes & 35 & $\simeq 20$ & Yes & Yes & Yes & Yes & - & - & Yes & Very few \\
\hline Phrenic nerve stimulation & 3 & - & $10-20$ & $10-20$ & 10 & No & - & - & 1 & - & No & 3 & - \\
\hline BiPAP & Yes $^{\dagger}$ & No & Yes & $\simeq 100$ & Yes & No & Yes & Probably & Yes & No & Exceptionally & Yes & Yes \\
\hline
\end{tabular}

*: ANTADIR: is in charge of $70 \%$ of the 40,000 patients receiving domiciliary respiratory care in France. The other $30 \%$ are in the charge of commercial companies. ${ }^{\dagger}$ : rapidly growing - not yet reimbursed. -: not known. LTOT: long-term oxygen therapy; MV: mechanical ventilation; CPAP: continuous positive airway pressure; BiPAP: bilevel positive airway pressure; NHS: National Health Service. Ventilation: Int Neg P Ventilation: intermittent negative pressure ventilation.

Table 3. - Prescribers of home treatment and national recommendations

\begin{tabular}{|c|c|c|c|c|c|c|c|c|c|c|c|c|c|}
\hline & Belgium & Denmark & England & France & Germany & Ireland & Italy & $\begin{array}{l}\text { The } \\
\text { Netherlands }\end{array}$ & Norway & Poland & $\begin{array}{c}\text { Spain } \\
\text { (Catalonia) }\end{array}$ & Sweden & Switzerland \\
\hline $\begin{array}{l}\text { Prescribers of home } \\
\text { LTOT or MV }\end{array}$ & $\begin{array}{c}\text { Lung } \\
\text { physician } \\
+ \\
\text { paediatrician } \\
\text { essentially }\end{array}$ & $\begin{array}{l}\text { Varies } \\
\text { from } \\
\text { county to } \\
\text { county }\end{array}$ & $\begin{array}{c}\text { Lung } \\
\text { physician } \\
\text { suggests } \\
\text { and GP } \\
\text { prescribes }\end{array}$ & $\begin{array}{c}\text { Every } \\
\text { physician }\end{array}$ & $\begin{array}{c}\text { Every } \\
\text { physician }\end{array}$ & $\begin{array}{c}\text { Lung } \\
\text { physician } \\
+ \text { GP } \\
+ \text { public } \\
\text { health } \\
\text { doctor }\end{array}$ & $\begin{array}{c}\text { Lung } \\
\text { physician } \\
+ \\
\text { intensive } \\
\text { care } \\
\text { practitioner }\end{array}$ & $\begin{array}{c}\text { Every } \\
\text { physician } \\
\text { but } \\
\text { essentially } \\
\text { lung } \\
\text { physician }\end{array}$ & $\begin{array}{c}\text { Lung } \\
\text { physician } \\
+ \\
\text { internist }\end{array}$ & $\begin{array}{l}\text { Lung } \\
\text { physician }\end{array}$ & $\begin{array}{c}\text { Lung } \\
\text { physician } \\
+ \\
\text { intensive } \\
\text { care } \\
\text { practitioner }\end{array}$ & $\begin{array}{c}\text { Lung } \\
\text { physician } \\
+ \\
\text { paediatrician }\end{array}$ & $\begin{array}{l}\text { LTOT: } \\
\text { GP + lung } \\
\text { physician } \\
\text { MV: lung } \\
\text { physician } \\
\text { + care } \\
\text { practitioner }\end{array}$ \\
\hline $\begin{array}{l}\text { National prescription } \\
\text { rules }\end{array}$ & Yes & No & $\begin{array}{c}\text { Only for } \\
\text { LTOT by } \\
\text { concentrators }\end{array}$ & $\begin{array}{c}\text { For LTOT } \\
\text { only }\end{array}$ & Yes & $\begin{array}{l}\text { Varies } \\
\text { from } \\
\text { county to } \\
\text { county }\end{array}$ & No & No & $\begin{array}{l}\text { For LTOT } \\
\text { and MV }\end{array}$ & $\begin{array}{l}\text { for LTOT } \\
\text { only }\end{array}$ & Yes & $\begin{array}{l}\text { For LTOT } \\
\text { only }\end{array}$ & Yes \\
\hline
\end{tabular}


Table 4. - Supply of equipment, home supervision of patients and equipment, and financial organization

\begin{tabular}{|c|c|c|c|c|c|c|c|c|c|c|c|c|c|}
\hline & Belgium & Denmark & England & France & Germany & Ireland & Italy & $\begin{array}{l}\text { The } \\
\text { Netherlands }\end{array}$ & Norway & Poland & $\begin{array}{c}\text { Spain } \\
\text { (Catalonia) }\end{array}$ & Sweden & Switzerland \\
\hline $\begin{array}{l}\text { Distribution systems } \\
\text { (Supply of equipment) }\end{array}$ & $\begin{array}{c}\text { Hospital or } \\
\text { commercial } \\
\text { companies }\end{array}$ & $\begin{array}{c}\text { Commercial } \\
\text { companies }\end{array}$ & $\begin{array}{c}\text { LTOT: } \\
\text { commercial } \\
\text { companies } \\
\text { MV: } \\
\text { hospitals } \\
\text { CPAP: } \\
\text { hospital/NHS } \\
\text { /or private } \\
\text { purchase }\end{array}$ & $\begin{array}{c}\text { ANTADIR } \\
(70 \%) \\
\text { Commercial } \\
\text { companies } \\
30 \%\end{array}$ & $\begin{array}{c}\text { Commercial } \\
\text { companies }\end{array}$ & $\begin{array}{c}\text { LTOT: } \\
\text { commercial } \\
\text { companies } \\
\text { MV: } \\
\text { hospitals }\end{array}$ & $\begin{array}{c}\text { Commercial } \\
\text { companies }\end{array}$ & $\begin{array}{c}\text { Centre for } \\
\text { home MV } \\
+ \\
\text { commercial } \\
\text { companies }\end{array}$ & $\begin{array}{c}\text { LTOT: } \\
\text { commercial } \\
\text { companies } \\
\text { MV: } \\
\text { local } \\
\text { hospitals }\end{array}$ & NHS & $\begin{array}{c}\text { Commercial } \\
\text { companies }\end{array}$ & $\begin{array}{c}\text { Liquid gas: } \\
\text { commercial } \\
\text { companies } \\
\text { Others: } \\
\text { local } \\
\text { hospital }\end{array}$ & $\begin{array}{c}\text { LTOT: } \\
\text { national lung } \\
\text { organization } \\
\text { MV: } \\
\text { commercial } \\
\text { companies }\end{array}$ \\
\hline
\end{tabular}

Home supervision of:

\begin{tabular}{|c|c|c|c|c|c|c|c|c|c|c|c|c|c|}
\hline Patients & $\begin{array}{l}\text { Nurse } \\
\text { (technician } \\
\text { occasionally) }\end{array}$ & $\begin{array}{l}\text { Nurse, } \\
\text { doctor, } \\
\text { technician }\end{array}$ & $\begin{array}{c}\text { GP } \\
+ \\
\text { sometimes } \\
\text { nurse }\end{array}$ & $\begin{array}{l}\text { Nurse, } \\
\text { technician }\end{array}$ & $\begin{array}{l}\text { Doctor, } \\
\text { technician }\end{array}$ & $\begin{array}{l}\text { LTOT: GP } \\
\text { Concentrators: } \\
\text { technician } \\
\text { from } \\
\text { companies }\end{array}$ & $\begin{array}{l}\text { Doctor, } \\
\text { nurse }\end{array}$ & $\begin{array}{c}\text { Doctor, } \\
\text { social nurse, } \\
\text { technician }\end{array}$ & $\begin{array}{l}\text { Doctor, } \\
\text { nurse, } \\
\text { technician }\end{array}$ & $\begin{array}{c}\text { Doctor } \\
\text { nurse }\end{array}$ & Nurse & $\begin{array}{c}\text { National lung } \\
\text { organization } \\
+ \\
\text { technician }\end{array}$ & $\begin{array}{l}\text { National lung } \\
\text { organization }\end{array}$ \\
\hline Equipment & $\begin{array}{c}\text { Technician } \\
\text { from hospital } \\
\text { or commercial } \\
\text { company }\end{array}$ & Technician & $\begin{array}{l}\text { Commercial } \\
\text { company }\end{array}$ & Technician & Technician & - & Technician & $\begin{array}{l}\text { Centre for } \\
\text { home MV + } \\
\text { commercial } \\
\text { companies }\end{array}$ & NHS & $\begin{array}{l}\text { Commercial } \\
\text { companies }\end{array}$ & $\begin{array}{l}\text { Commercial } \\
\text { companies }\end{array}$ & $\begin{array}{c}\text { National lung } \\
\text { organization } \\
+ \\
\text { technician }\end{array}$ & $\begin{array}{l}\text { National lung } \\
\text { organization }\end{array}$ \\
\hline \multicolumn{14}{|c|}{$\begin{array}{l}\text { Who is in charge } \\
\text { of the costs of: }\end{array}$} \\
\hline LTOT & NHS & NHS & NHS & NHS & $\begin{array}{c}\text { Public \& } \\
\text { private } \\
(\mathrm{N}) \mathrm{HS}\end{array}$ & NHS & NHS & $\begin{array}{l}\text { NHS and } \\
\text { medical } \\
\text { insurance }\end{array}$ & NHS & NHS & NHS & $\begin{array}{c}\text { NHS } \\
\text { local county }\end{array}$ & $\begin{array}{c}\text { Medical } \\
\text { insurance } \\
\text { companies } \\
\text { and national }\end{array}$ \\
\hline MV & NHS & NHS & NHS & NHS & (N)HS & NHS & NHS & companies & NHS & NHS & NHS & $\begin{array}{l}\text { NHS local } \\
\text { county }\end{array}$ & $\begin{array}{c}\text { lung } \\
\text { organization }\end{array}$ \\
\hline CPAP & NHS & NHS & NHS & $\begin{array}{c}\text { On } \\
\text { discussion }\end{array}$ & $(\mathrm{N}) \mathrm{HS}$ & $\begin{array}{l}\text { Patients rent } \\
\text { or buy } \\
\text { CPAP, } \\
\text { sometimes } \\
\text { NHS }\end{array}$ & $\begin{array}{c}\text { CPAP } \\
\text { reimbursed } \\
\text { in some } \\
\text { cases }\end{array}$ & NHS & NHS & NHS & NHS & $\begin{array}{c}\text { NHS } \\
\text { some local } \\
\text { counties }\end{array}$ & \\
\hline
\end{tabular}

For abbreviations see legend to tables 3 and 4 . 
number of negative pressure ventilators. Negative pressure ventilation for neuromuscular disease is also used in Sweden, Italy and in one centre in The Netherlands. Only 35 patients $(0.5 \%$ of the patients under the auspices of ANTADIR receiving home MV) are thought to receive this treatment in France.

\section{Regulation of prescription}

In Europe, every physician may prescribe home LTOT or MV (table 3). The situation is complicated in Denmark and The Netherlands where treatments may be prescribed by nonspecialist physicians. In England, physicians advise on LTOT but the family doctor prescribes the treatment.

In Belgium, Catalonia, Italy, Germany, Poland [5], and Ireland, fewer physicians prescribe home treatments for CRI and national guidelines advise correct prescription. In Germany, some health insurance companies monitor correct prescription. LTOT can be prescribed by any physician but reimbursement rules and the national register have ensured that LTOT is rarely prescribed by other than chest physicians in Sweden [4], and the guidelines issued by the Swedish Society of Chest Medicine are well adhered to. Oxygen is prescribed for a mean of around $18 \mathrm{~h} \cdot \mathrm{day}^{-1}$ and compliance is satisfactory in approximately $70 \%$ of the patients [4].

Prescription rules exist in France, Great Britain, Poland and some regions of Spain for LTOT only and in Germany, Spain (Catalonia), Belgium [18, 19] and Switzerland [20-22] both for LTOT and MV. The latter country is the only one with an element of control of prescription. Review of its experience on adherence to guidelines and patient's compliance has been published [23, 24]. In Sweden [4], Norway, Poland [5] and Italy, recommendations have been created by specialists in the absence of national guidelines. A survey in Ireland in 1986 revealed that 28 of the 32 community care areas would welcome national guidelines on LTOT.

\section{Organization of supply of equipment and home supervision}

Equipment supply is provided by commercial companies, hospitals or national organizations, and health services, both nationalized and private (table 4). A combination of different suppliers exists in Belgium, Great Britain, France and Switzerland. In Norway, the National Health Service buys the MV equipment and gives it to the patient for as long as necessary, but oxygen is provided by commercial companies.

Home supervision of the patients is usually performed by medical and/or nursing personnel and occasionally by technical staff, but its quality is highly variable (table 4). For LTOT, equipment is supervised by a technician in all countries. There is technical support for the equipment, usually provided by the commercial companies. MV is usually supervised by clinicians (The Netherlands, Ireland, Great Britain, Switzerland). In Italy, no systematic home supervision is organized for patients with CRI but rehabilitation centres and home care services based on voluntary associations supply this to some patients.

\section{Costs}

In nearly all countries, the National Health Service is responsible for the costs of LTOT and MV (table 4). Exceptions are Sweden, where the local county provides concentrators, ventilators, CPAP and mobile oxygen, and The Netherlands where medical insurance companies participate to reimburse LTOT but not MV. In Switzerland, all therapeutic costs are supported by medical insurance companies in collaboration with the specialized Association for Tuberculosis and Pulmonary Diseases. In Italy, patients rent or buy their own CPAP equipment. In Belgium, the national social security allows mutual medical insurance companies to pay for home treatment for CRI prescribed in approved hospital departments [18, 19]. In all countries, cost includes home installation and supervision of equipment, except in England and Wales, where this only applies to oxygen concentrators.

\section{Discussion}

Chronic chest disease affects more disabled individuals than almost any other disorder. Many develop respiratory failure, which will ultimately cause death. The nature of the disease demands treatment for periods between several months and several years. Home care is the only reasonable treatment method but requires a cocktail of support modalities unfamiliar to the hospital environment.

This paper defines categories for two treatments where information from European countries is available. In many countries, the information is incomplete, erratic in its detail and characterized only by its paucity for outcome modalities. The cost of chronic care is overwhelming most National Health Services. Cost benefit analyses of costly treatments must eventually be possible.

The major differences between countries are the existence or not of a national register, the prescribers of home treatment, the prescription rules which are implemented only in some countries, and the equipment used at home for LTOT and MV. These differences are explained by the historical origin of home care in each country, the different impact of commercial companies, and the supervision of insurance companies on doctor's prescriptions. The differences in reimbursement systems and in organization of home care explain the differences of costs.

The object of treatment by LTOT or MV is increased survival and improved quality of life. After the two large trials [2, 3] limited data have since been published. A number of countries are capable of collecting data through their registers, and all should do so. Quality of life is currently difficult to measure but specific questionnaires are being developed. Most countries know precisely or approximately how many patients are treated. The most successful data collection is undertaken through national 
Thoracic Societies. This could become a model for the less well-organized countries, such as the UK [16] and The Netherlands.

Therapeutic guidelines are variously written; some countries have none at all. Surely, the European Respiratory Society should organize uniform guidelines with representatives of national societies? The guidelines would include criteria for patient selection, evaluation and monitoring.

Equipment used for LTOT and MV has been successfully evaluated in France through the ANTADIR organization [25]. Sporadic reports emanate from other countries. A central group could monitor equipment performance and its maintenance. Home care is a research as well as a therapeutic area. The multiplicity of systems throughout Europe demonstrates that no ideal mechanism has yet been found. The type of care worker, specialist or generalist with specialist training, has still to be agreed. The part to be played by general practitioners and consultants is far from clear. Chronic care is moving into the home, collaborative comparison of equipment type and performance would be most valuable. Financially disadvantageous systems exist in some countries. Presumably, Health Service finance directors might correct such anomalies, if they were aware of them.

Important differences exist between countries in Europe in home treatment of chronic respiratory disease. Comparative analysis should help achieve uniform standards and provide a basis for future research.

\section{References}

1. Donner CF, Howard P, Robert D. Patient selection and techniques for home mechanical ventilation. Monaldi Arch Chest Dis 1993; 48: 40-47.

2. Medical Research Council Working Party. Long-term domiciliary oxygen therapy in chronic hypoxic cor pulmonale complicating chronic bronchitis and emphysema. Lancet 1981; i: 681-686.

3. Nocturnal Oxygen Therapy Trial Group. Continuous or nocturnal oxygen therapy in hypoxaemic chronic obstructive airways disease: a clinical trial. Ann Intern Med 1980; 93: 391-398.

4. Ström K, Boe J. A national register for long-term oxygen therapy in chronic hypoxemia: preliminary results. Eur Respir J 1988; 1: 952-958.

5. Gorecka D, Sliwinski P, Zielinski J. Adherence to entry criteria and one year experience of long-term oxygen therapy in Poland. Eur Respir J 1992; 5: 848-852.

6. Ström K, Boe J. The Swedish Society of Chest Medicine. Quality assessment and predictors of survival in longterm domiciliary oxygen therapy. Eur Respir J 1991; 4: $50-58$.

7. Ström K, Pehrsson K, Boe J, Nachemson A. Survival of patients with severe thoracic spine deformities receiving domiciliary oxygen therapy. Chest 1992; 102: 164-168.

8. Ström K, the Swedish Society of Chest Medicine. Survival of patients with chronic obstructive pulmonary disease receiving long-term domiciliary oxygen therapy. Am Rev Respir Dis 1993; 147: 585-591.
9. Ström K, Boman G, the Swedish Society of Chest Medicine. Long-term oxygen therapy in parenchymal lung diseases: an analysis of survival. Eur Respir J 1993; 6: 1264-1270.

10. Chailleux E, ANTADIR. A prognostic index of survival for COPD patients on long-term oxygen therapy: a study of 1,063 patients from the ANTADIR register. Am Rev Respir Dis 1993; 147: A324.

11. ANTADIR, Chailleux E, Binet F, Sadoul P. Facteurs pronostiques de la survie des insuffisants respiratoires obstructifs traités par oxygénothérapie à long-terme: données de l'observatoire de l'ANTADIR. Rev Mal Respir 1992; 9: 603-611.

12. Healy E, Kelly P, Clancy L. Long-term home oxygen; current practices in Ireland. Irish Med J 1993; 86: 6263.

13. Keller R, Ragaz A, Borer P. Predictors for early mortality in patients with long-term oxygen home therapy. Respiration 1985; 48: 216-221.

14. Granados A, Escarrabill J, Soler M. Situacion de la oxigenoteràpia domiciliària en Cataluna. Arch Bronconeumol 1992; 28: 264-266.

15. Ordre de 10 d'octubre de 1990 , de regulacio de la prestacio del servei d'oxigenoteràpia domiciliària amb mitjans concertats. Departament de Sanitat i Seguretat Social. Diari Oficial de la Generalitat de Cataluna. $\quad \mathrm{N}^{\circ} 1357$; 22/10/1990; 4740-4741.

16. Howard P. Home mechanical ventilation and respiratory care in the United Kingdom. Eur Respir Rev 1992; 2: 416-417.

17. Durieux P, Neukirch F. Epidemiologie du syndrome d'apnées du sommeil de l'adulte. Rev Mal Respir 1990; 7: 441-449.

18. Institut National Assurance-Maladie-Invalidité (INAMI). Convention entre le Comité de Gestion du Service des Soins de Santé de l'INAMI et les Services Hospitaliers. "Oxygénothérapie de longue durée à domicile par concentrateur ou par oxygène liquide". B-1150 Bruxelles - Belgique.

19. Institut National Assurance-Maladie-Invalidité (INAMI). Convention entre le Comité de Gestion du Service des Soins de Santé de l'INAMI et les Services Hospitaliers. "Assistance ventilatoire mécanique au long cours à domicile". B-1150 Bruxelles - Belgique.

20. Association suisse contre la Tuberculose et les Maladies Pulmonaires. Direction pour l'oxygénothérapie continue à domicile des insuffisants respiratoires. Bull Office Féd Santé Publ. Annexe C, 22.06.1989.

21. Association suisse contre la Tuberculose et les Maladies Pulmonaires. Oxygénothérapie ambulatoire à l'aide d'appareils portables. Bull Office Féd Santé Publ. Annexe C, 22.06.1989.

22. Association suisse contre la Tuberculose et les Maladies Pulmonaires. Lignes directrices pour la ventilation mécanique à domicile. Bull Office Féd Santé Publ. Annexe C, 17.06.1991.

23. Bongard JP, De Haller R. Oxygénothérapie au long cours en Suisse. Schweiz Med Wschr 1989; 119: 110-115.

24. Chevrolet JCl, Fitting JW, Domenighetti G, Knoblauch A. Ventilation mécanique à domicile en Suisse en 1990. Schweiz Med Wschr 1991; 121: 368-377.

25. Muir JF, Voisin C, Ludot A. Home mechanical ventilation (HMV). National Insurance System (France). Eur Respir Rev 1992; 2: 418-421. 